\title{
A Esperança como Teologia da História Relendo as nossas Conferências Episcopais
}

Lina Boff

A esperança é apresentada nas conclusões dos nossos documentos Medellín, Puebla, Santo Domingo e Aparecida - num contexto histórico que nos exigiu uma leitura teológica dos elementos históricos aí presentes na vida concreta dos nossos povos. Não estudaremos a teologia da história dos sistemas abertos. Pretende-se fazer uma leitura teológica da história como a entendemos na teologia, isto é, à luz da fé que professamos na História da Salvação, que é a maneira com que Deus se revelou e continua se revelando a toda a humanidade. Daí a nossa fé ser histórica. Pois, a história é campo da revelação de Deus como também é campo da negação desse mesmo Deus.

A obra que mais influenciou a teologia da história, sobretudo no Ocidente, foi a de Agostinho com sua apologética De Civitate Dei, A cidade de Deus, em que mostra a luta entre o sistema divino e os sistemas anti-divinos, luta da qual, o primeiro sairá vitorioso no cumprimento eterno e transcendente da história. Nesta obra Agostinho alarga o campo da sua consideração, elaborando uma vasta teologia da história, que terá grande influência sobre a Idade Medieval até Bossuet ${ }^{1}$. Este amplo trabalho apologético, defende - a partir de uma determinada conjuntura - a fé cristã, propondo uma teologia da história da salvação que abraça, concretamente, também a história humana.

Ao fazer a opção de não estudar a teologia da história dos sistemas abertos, mas a história lida à luz da teologia, reconhecemos que a história é

\footnotetext{
${ }^{1}$ Sugere-se a leitura comentada da obra Storia dei Dogmi IV, sob a direção de Bernard SEBOÜE, Casale Monferrato, Piemme, 1998, p. 36-38.
} 
ambígua: ela apresenta subidas e descidas que precisa interpretá-las. Nesta interpretação deve-se incluir toda a história da criação e do pecado, toda a história da aliança e da quebra desta aliança pela infidelidade do povo escolhido. Deve-se incluir toda a história que constitui o eixo em torno ao qual nos movemos e que será sempre a história de Jesus que o levou ao mistério pascal: na quinta-feira santa, Jesus reconcilia a humanidade com o Pai; na sexta-feira, Jesus passa pela negação e a traição chegando à morte; no sábado, a esperança se destrói, há sepultamento de tudo, é a total desesperança que se manifesta nos discípulos de Emaús: o horizonte da vida e da esperança desaparece para eles; no domingo, depois de todo este acontecimento, irrompe a ressurreição que traz a vida em plenitude para a humanidade e se refaz a esperança que inaugura a nova história.

A esperança como teologia da história, neste artigo, não é concebida só como virtude teologal, mas é o momento em que a fé-esperança se encontra com a história, não só como seu espaço em que brota a vida aberta à plenitude da graça, mas essencialmente, como sentido que pertence ao Mistério ${ }^{2}$.

\section{A esperança como teologia da história na intuição do Vaticano II}

Para todo este parágrafo e demais comentários ao longo do artigo, utilizamos a obra de Baraúna ${ }^{3}$. Para a Igreja, o Vaticano II é considerado um evento histórico com sua originalidade única: este Concílio inaugura um processo que abre a Igreja para a história universal, tornando-se assim um sinal dessa história. Em todos os documentos do Vaticano II encontramos elementos de uma teologia da história vivida em contexto de esperança, elementos que, aplicados às Conferências Episcopais, realizadas em nosso Continente, descobre-se que essa esperança é vivida pelos nossos povos que buscam construir uma nova história. Como exemplo, fazemos referência de modo especial, à Constituição Pastoral Gaudium et Spes, que, interpretada e aplicada à nossa realidade continental, pode-se dizer, que as dores e esperanças dos pobres são também as dores e esperanças da Igreja deste Continente, pois a grande maioria da Igreja que aqui vive sua fé cristã é constituída pelos pobres.

Diante da realidade do mundo e da sociedade, sobretudo européia daquele tempo, os documentos do Concílio Vaticano II procuram recuperar o

\footnotetext{
${ }^{2}$ Cf. FISICHELlA, R., "Teologia della Storia”, in Dizionario di Teologia Fondamentale, Assisi, Cittadella Editrice, 1990, p. 1185 e BOFF, Cl., "O caso da Teologia da História", in Teologia e Prática. Teologia do Político e suas mediações, Petrópolis, Vozes, 1982, p. 108-109.

${ }^{3}$ Cf. BARAÚNA, G., A Igreja no Mundo de Hoje, Petrópolis, Vozes, 1967, p. 1174-1179.
} 
que é bom da ciência, da técnica e de todos os valores do mundo moderno europeu. Esta visão dos padres conciliares é evidente, sobretudo, na Constituição Gaudium et Spes. Mas esta não tem âncora para extrair dela uma teologia da história marcada pela esperança cristã. Enquanto a Europa idealiza uma nova sociedade com sua abertura ao mundo moderno, nós na América Latina lemos e interpretamos a realidade a partir do caos e da exclusão progressiva, clama-se por libertação e caminha-se em direção ao povo. A base do Vaticano II é o mundo moderno, a base de Medellín é o caos e a paixão do povo.

Neste horizonte, dado pela ótica latino-americana, que concebe a Igreja caminhando em direção às massas pobres e excluídas, a abertura da Igreja conciliar européia, nos parece otimista demais e até mesmo um tanto ingênua, não para aquele tempo em que o Vaticano II foi pensado e realizado pelos padres conciliares, mas para nós hoje, com uma visão eclesial abrangente e aberta. Este Concílio deve ser entendido no transfundo católico e cristão daqueles anos para a Europa; e deve ser pensado e interpretado de maneira profética na sua aplicação para a América Latina, que começou com Medellín.

O evento Vaticano II reconcilia a Igreja com o mundo moderno depois de duas grandes catástrofes que foram as guerras mundiais com seus efeitos que até hoje nos ressentimos deste drama mundial. Depois disso a Igreja abre-se e quer se reconciliar com o mundo moderno e nesse sentido foi providencial e muito necessário fazê- $10^{4}$. Só que a sociedade moderna caminhou muito mais à frente e hoje podemos levantar questões que abrem uma dialética sadia para que a reflexão teológica não seja linear sobre questões urgentes, face a um passado triunfante e otimista demais.

As nossas Conferências Episcopais traçaram orientações de seu plano de evangelização, que continuam contendo elementos inovadores, os quais ultrapassam as próprias orientações dadas pelo Vaticano II, sempre porém, declarando sua fidelidade ao mesmo 5 .

Contemporaneamente, desenvolveu-se uma reflexão teológica que nascia da realidade de cada Igreja local, tendo como inspiração e ponto de referência, os documentos do Vaticano II. Tal processo deu à Igreja vivida em pequenas e grandes comunidades, traços típicos de sua cultura e de seu

\footnotetext{
${ }^{4}$ Cf. CONGAR, Y., “A recepção como realidade eclesiológica”, in Concilium/77 (1977), p. 886-907.

${ }^{5}$ Cf. ANTÓN, A., "Eclesiologia postconciliare: speranze, risultati e prospettive", in Vaticano II: bilancio e prospettive, venticinque anni dopo, 1962/1987, Assisi, Cittadella Editrice, 1987, p. 362ss.
} 
modo original de viver a fé cristã, as quais passaram a mudar sua realidade sócio-cultural e tradição religiosa. Deste modo superou-se a concepção de uma teologia da história oriunda da Europa, sem a devida articulação com a realidade dos povos dos cinco Continentes. Cria-se então uma conscientização que leva em conta o mal que se encontra embutido na realidade humana e estrutural, levando cada pessoa e sua comunidade de fé, a assumir o compromisso histórico de transformar as condições de vida que alimenta a esperança por dias melhores e vive sua índole religiosa fundada nas verdades da fé cristã.

A necessidade urgente de uma visão teológica capaz de abranger, quer os elementos permanentes da revelação, quer os dados históricos da condição humana, foi a intuição de fundo de João XXIII, que ao convocar os bispos do mundo inteiro para abrir as portas e as janelas da Igreja que se encontravam travadas, queria dar à verdade da fé uma formulação inteligível ao mundo moderno, sem tocar a substância desta verdade, dado que uma coisa é a essência da verdade da fé e outra é seu revestimento. Estas indicações constituíram o plano metodológico de todo o trabalho conciliar ${ }^{6}$. Na Gaudium et Spes, ressaltam-se as muitas evocações da presença de Cristo na história, das relações da esperança da Igreja com a história e do agir humano que faz história com a graça trazida por Cristo ${ }^{7}$.

Enquanto a reflexão teológica originada de grande parte das Conferências Episcopais dos diferentes Continentes teve como base o mundo moderno e o avanço das ciências aplicadas à técnica, no nosso Continente, esta leitura feita à luz da fé, teve como base o sofrimento e as esperanças do povo, com o encontro da Igreja e os empobrecidos e excluídos de quase meio milênio da nossa evangelização ${ }^{8}$. É o tempo em que a velha história oferece suas raízes cristãs para a construção de uma nova história que explicite, na vida e nas suas estruturas seculares, o Plano amoroso do Pai ${ }^{9}$.

Encontra-se aqui, a esperança como teologia da história porque é apreendida como história humana aberta a este Plano. Toma-se consciência de que a esperança vivida e experimentada por Jesus com o povo de Israel, se inscreve na história humana dos nossos povos. A esperança do povo de Israel é realizada por Jesus que entra na história humana ${ }^{10}$ com sua encarnação e

\footnotetext{
${ }^{6}$ Cf. BARAÚNA, G., A Igreja no Mundo de Hoje, Petrópolis, Vozes, 1967, p. 174-1179.

${ }^{7}$ Cf, TILLARD, J. M., "A Igreja e os valores terrestres", in A Igreja no Mundo de Hoje, o. c., p. 223.

${ }^{8}$ Cf. IMPERATORI, M., H. U. von Balthasar: Uma teologia drammatica della storia, Pubblicazione del Pontifício Seminário Lombardo in Roma, 2001, p. IX-X.

${ }^{9}$ Cf. CHENU, M-D., “A missão da Igreja no Mundo de hoje”: referência à alocução de Paulo VI em 3 de fevereiro de 1965.

${ }^{9}$ Cf. CHENU, M-D., “A missão da Igreja no Mundo de Hoje”, in Baraúna, o. c. , p. 344.

${ }^{10}$ Cf. SMULDERS, P., "A atividade humana no mundo", in A Igreja no Mundo de Hoje, o. c., p. 340.
} 
realiza a esperança vivida pelo povo de Israel $^{11}$, mas atualizada e assumida em nosso Continente. A esperança que cria uma história iluminada pela fé, não diminui o valor e a importância de todas as coisas criadas e as realizações terrenas, mas antes as incentiva para que estas realizem seus fins, sempre com novas motivações. Esta leitura levou os bispos do Continente às conclusões de Medellín.

\section{A esperança em Medellín}

A apresentação do documento de Medellín feita pelo presidente da CELAM, em 1968, convida todos os bispos a viverem a mesma inquietude, o mesmo compromisso e a mesma esperança, pois, "sobre o Continente latino-americano Deus projetou uma imensa Luz que resplandece no rosto de sua Igreja. É a hora da esperança"12. Medellín foi mais que a aplicação do Vaticano II em nosso Continente, superando a proposta do próprio Paulo VI ao convocar esta Conferência ${ }^{13}$. Paulo VI abre esta II Conferência dada em Medellín-Colômbia, priorizando a orientação pastoral da Gaudium et Spes. Neste discurso enfatiza o dever da Igreja de apoiar os programas que promovem a justiça, beneficiam as populações mais pobres e sobretudo os programas marcados com o selo da justiça. O progresso e o desenvolvimento integral, são também enfatizados ao citar o primeiro aniversário da Populorum Progressio junto com as demais Encíclicas Sociais publicadas pelas Conferências Episcopais do Continente e pelo magistério. Nestes princípios os bispos são convidados a encontrarem orientação e luz para uma nova ordem inspirada na prática de Jesus Cristo ${ }^{14}$.

Todo o documento se apresenta pervadido da história sofrida do povo por um lado, mas por outro, coberto de esperança como o povo do Êxodo que se liberta da escravidão do Egito e caminha ao encontro da terra prometida, na esperança de sua libertação que se realiza com a vinda do Messias anunciado pelos Profetas. Medellín respira esperança, esperança vivida na história concreta e vinculada à história da salvação. Assim se expressam os bispos que presidem a CELAM daquele momento, dom Avelar Brandão Vilela e dom Eduardo Pirônio: Deus projetou uma imensa luz que resplande-

\footnotetext{
${ }^{11}$ Referência à alocução de Paulo VI em 3 de fevereiro de 1965.

12 Documento de Medellín, Dom Avelar Brandão Vilela, presidente do CELAM e Dom Eduardo Pirônio, Secretário Geral do CELAM, Bogotá, 30 de novembro de 1968.

${ }^{13}$ Cf. LIBANIO, J. B., Conferências Gerais do Episcopado Latino Americano do Rio de Janeiro a Aparecida, S. Paulo, Paulus2007, p. 21s.

${ }^{14}$ Cf. Documento de Medellín, p. 16, parágrafo III.
} 
ce no rosto de sua Igreja, pois é a hora da esperança cristã se manifestar na resposta de todo o povo de Deus da América Latina. E concluem afirmando que esta resposta exige profundidade na oração, maturidade nas decisões e generosidade nas tarefas ${ }^{15}$.

Ao se referir às orientações dadas por Paulo VI, o cardeal Landázuri afirma que a Igreja deve manifestar a sua vitalidade e valer-se plenamente, das suas grandes possibilidades de ação, com uma pastoral dinâmica, que seja uma resposta à esperança que os povos do Continente depositam na Igreja e que seja adequada ao ritmo da transformação em curso, pois os desafios urgem uma tomada de posição evangélica que promova a dignidade de povos que vivem sua fé cristã, já secular, mas ainda não libertada do mal e do pecado ${ }^{16}$. As expectativas e as esperanças vividas na preparação do evento de Medellín, eram propostas como o começo de uma nova etapa histórica da América Latina, intimamente vinculada à história da salvação.

A esperança como teologia da história é concebida a partir da realidade injusta e inumana dos pobres, realidade que não só perpassa todo o documento, mas vai além do que foi escrito neste documento. A dor dos pobres encontra, na voz dos bispos, a esperança que parecia estar ausente da história, esvaziando-a de sentido. A reflexão sobre a realidade, feita à luz da revelação e das orientações conciliares, é apresentada, no documento, dando destaque a estas dimensões da vida: à promoção humana, diante da opressão e da injustiça; à evangelização e o crescimento da fé, diante de um cristianismo sem compromisso; à Igreja visível e suas estruturas, diante de um aparato eclesiástico longe dos pobres e do povo em geral $^{17}$.

Não obstante a preocupação que os bispos manifestam, publicamente, eles se confessam "homens de esperança" em meio a um povo sofrido e injustiçado $^{18}$. Como homens de esperança concentram seu trabalho em dar uma resposta pastoral de esperança, aos desafios que exigiam o compromisso da fé cristã com a história no seu todo e com a história daquele momento. Inspirados na Gaudium et Spes, assumem a metodologia do VER-JULGARAGIR na prática pastoral. Dão centralidade à Palavra de Deus na Bíblia que passou a ser manuseada pelo povo e interpretada nos distintos grupos eclesi-

${ }^{15}$ Cf. Apresentação do documento feita por D. Avelar Brandão Vilela, então presidente da CELAM e D. Eduardo F. Pirônio, secretário geral da CELAM

${ }^{16}$ Cf. Documento de Medellín, p. 10: O pontífice apresenta o futuro da evangelização do Continente motivando os bispos para a construção de um futuro que lhes pede esforço, audácia e sacrifício. A esta motivação se refere o Discurso de abertura do cardeal Juan Landázuri Ricketts, 14, que cita: "Exortação ao Episcopado Latino-Americano", in REB, volume XXVI de 24-11-1965, p. 146; GS, 39.

17 "Discurso do cardeal Landázuri”, citado acima.

${ }^{18}$ Documento de Medellín, 1.II, 5 
ais, sobretudo nas Comunidades Eclesiais de Base - as CEBS. Foi assim que o povo aprendeu enfrentar as tensões sociais, políticas e também eclesiásticas de cada tempo. E foi esta consciência histórica do povo que o levou a discernir os "sinais dos tempos" como sinais da revelação de Deus, na história, responder a eles com esperança e acreditando na ação divina em estreita relação com a prática e a missão de cada pessoa e de todo o povo de Deus.

Todo esse processo, visto como caminhada de fé, tinha um momento alto na celebração litúrgica, tempo forte que proclama a esperança vivida e experimentada na história humana, como realidade antecipatória da vida plena $^{19}$. A sacralidade da vida abre-se para a esperança por dias melhores e a celebração se torna um lugar da vinculação profunda que existe entre o plano salvífico de Deus, realizado em Cristo, e as aspirações humanas dos nossos povos; entre a história da salvação e a história humana; entre a ação reveladora de Deus e a experiência das comunidades de fé que vivem os valores temporais. Esta unidade que exclui a dicotomia da vida temporal com a vida eterna, tem sua expressão mais alta na liturgia.

A esperança, que marca, fortemente, a celebração litúrgica, com a tensão entre o que já é uma realidade e o que ainda não se verifica, plenamente, celebra a assunção de esperanças intra-históricas de determinados fatos, à assunção de esperanças trans-históricas, que, fatos da história humana, são elevados à história da salvação. Esta celebração tem um sentido de alegre esperança e ao mesmo tempo, de profunda consciência de pecado e limitação humana. Numa palavra, a comunidade que celebra vive na esperança dentro da história que constrói ${ }^{20}$.

Medellín prossegue afirmando que, o processo evangelizador não pode desconhecer a tensão que a esperança gera nas comunidades de fé enquanto vivem a expectação de Deus na história, que se constrói na diversidade das formas, através das quais, Deus em seu mistério, se revela de maneira a transcender a nossa limitação e pobreza. Viver a esperança significa esperar Deus cada dia e acolhê-lo na irrupção do futuro. Nesse sentido a esperança é concebida como teologia da história, pois tem a missão de assumir os

\footnotetext{
${ }^{19}$ Cf. Documento de Medellín, 8,4.

${ }^{20}$ O Documento de Medellín, em 9,2, cita a LG, 48 que fala da Igreja peregrina e a SC, 2 e 8 , apresentam a característica da Igreja visível que celebra, na esperança, pois é a um tempo humana e divina, visível, mas ornada de dons invisíveis, operosa, mas ao mesmo tempo contemplativa, presente no mundo e construindo a Cidade futura que esperamos dentro da história humana.
} 
fatos históricos que elevam e transcendem a história humana para fazer desta, a história da salvação ${ }^{21}$.

A proposta inicial de fazer uma releitura das nossas Conferências na ótica da esperança como teologia da história, com o objetivo de dar um sentido teológico à história em que a esperança é vivida e proposta num determinado contexto histórico, é positiva: primeiro, porque a esperança que tem como objeto Jesus Cristo, atua como categoria histórica que dá sentido teológico à concretude dos fatos da caminhada de fé dos povos latinoamericanos e caribenhos. Segundo, porque constatamos que esta releitura nos levou a uma concepção de esperança como teologia da história, que transforma a vida no seu sentido integral, para que esta vida se realize na vivência da antecipação do mistério divino. Dentro desta concepção constatamos também que, os fatos e os acontecimentos, de maior significação positiva, como os de significação negativa, passam a ser lidos e interpretados, recriando-lhes o sentido originário de Deus em seu mistério.

\section{Ressonâncias teológicas vindas do contexto histórico}

Em Medellín, a esperança como teologia da história, não nasce diretamente do testemunho e da prática evangelizadora das comunidades de fé, mas do anúncio profético e da mediação aberta dos bispos que emprestam sua voz a estas comunidades espalhadas por todo o Brasil e o Continente, comunidades necessitadas de representatividade e esta vem de seus pastores. Através dos bispos, os pobres encontram lugar e entram de maneira mais direta na Igreja. A vida inumana de pobreza e opressão na qual vivem, não é vontade de Deus, mas uma situação pecaminosa que precisa ser superada. $\mathrm{O}$ documento final fala, abertamente, que "um surdo clamor brota de milhões de pessoas, pedindo a seus pastores uma libertação que não lhes chega de nenhuma parte" 22 , mas chega-lhes da parte do Deus e Senhor da história, na qual se enraíza a esperança.

Nesse contexto, a esperança se faz teologia da história porque dá um sentido de fé aberta ao futuro às ações de Deus que se manifesta em estreita relação com a caminhada do povo que alimenta esperança nesse Deus ${ }^{23}$. Mas

${ }^{21}$ Documento de Medellín, 2,24. 11,18. Cf. SODI, M., "Celebrazione”, in Nuovo Dizionario di Liturgia, Roma, Paoline, 1984, p. 232, que interpreta as celebrações das comunidades de fé como sinal de abertura a todos os povos.

${ }^{22}$ Documento de Medellín, 14,2. Cf. AA.VV., Vida, clamor e esperança. Reflexões para os 500 anos de evangelização a partir da América Latina, S. Paulo, Loyola, 1992, p. 31s. 104s; 327s.

${ }^{23}$ Cf. MARADIAGA, cardenal O.A.R., "Recordando a Medellín", in Cuestiones Teológicas, Vol. 35, No. 84, julio - diciembre (2008), p. 227-233; TORNOS, A., Escatologia I, Madrid, UPCO, 1991, p. 121-177. 
a Conferência de Medellín destaca-se, de modo especial, pela histórica opção preferencial pelos pobres feita como prática e testemunho evangélicos. Os bispos da América Latina e Caribe insistiram no ensinamento e no exemplo de Jesus Cristo, nosso Salvador, que não apenas amou os pobres, mas, "sendo rico se fez pobre", viveu na pobreza, concentrou sua missão no anúncio da libertação dos pobres e fundou a Igreja como sinal dessa pobreza no meio de nós ${ }^{24}$.

O documento continua evidenciando o processo de evangelização do Continente e pede que seja acompanhado por uma teologia que leve à prática pastoral as comunidades de fé, conscientizando-as para a justiça social, vinculada à consciência histórica da salvação, atingindo seu ponto alto na celebração litúrgica. Nesse contexto, as celebrações litúrgicas ou não, rompem com o intimismo da fé que se expressa só no âmbito eclesial, abrem-se para um tipo de oração que inclui a vida, a família, as estruturas sociais, econômicas e culturais que dominavam o povo cristão. As pessoas começam a enxergar os sistemas que oprimem e impedem a construção de uma nova história como resposta às aspirações e esperanças por uma vida melhor e as tradições religiosas do povo são valorizadas. $\mathrm{O}$ acesso à Palavra da Bíblia, a sua proclamação e partilha, seja com a presença do padre ou sem ela, preparou a Igreja dos mais simples e pobres, para o compromisso, não só religioso de sua fé, mas também social e político. Tal processo desencadeia a mudança transformadora da sociedade e da própria Igreja, como instituição e serviço ao povo.

A esperança, portanto, move o povo crente a construir a história que tem como centro Deus atuando nessa história, através de Jesus Cristo que continua vivo pelo seu Espírito. Ao apresentarem as características da evangelização renovada, os bispos enfatizam a unidade profunda que deve existir entre o plano salvífico do Pai realizado em Cristo e as aspirações humanas, entre a história da salvação e a história humana ${ }^{25}$, pois esta deve estar aberta à realização escatológica celebrada na liturgia. Retomando o que já afirmamos, anteriormente, cabe dizer que, a celebração litúrgica, como as demais celebrações comunitárias, foi uma das ênfases que muito marcou o documento de Medellín. Em vários e diferentes parágrafos deste documento, esta foi evidenciada e colocada como ponto alto do processo evangelizador, espiritual, catequético e social-político.

\footnotetext{
${ }^{24}$ Cf. Documento de Medellín, 14, 7-10. 5,15.

${ }^{25}$ Cf. Ibid., 8.II, 4.
} 
Esta esperança como teologia da história é reconhecida também no tempo que escande o cotidiano, com a tomada de consciência do presente que impulsiona o Senhor da história; escande o passado que nos impele a fazer memória das maravilhas do nosso Deus; e nos faz entrever o futuro que nos leva a entregar-nos nas mãos da Providência divina. Esta sempre nos acompanha e nos orienta para o fim bom da nossa história construída no tempo.

Tal reflexão evoca e atualiza testemunhos da história da salvação, como o da oração que Judite faz em favor de seu povo, nos mostra o Senhor da história que se revela em tempos determinados pela sua vontade salvífica. Judite reza no tempo que a envolve e faz história, com estas palavras: "Tu Senhor, é que fizeste o passado, o que acontece agora e o que acontecerá depois; o presente e o futuro foram concebidos por ti, e o que tinhas em mente aconteceu. Teus desígnios se apresentaram e disseram: 'Aqui estamos!' Porque todos os teus caminhos estão preparados, e teus juízos previstos de antemão" (Jt 9, 5-6). A oração desta mulher é feita num contexto em que os acontecimentos se dão no tempo e no espaço, nos quais Deus age e faz história à frente de seu povo. Outro testemunho de uma das confissões de fé do povo de Israel, nos dá uma concepção de esperança vivida na história, na qual Deus se revela e se dá a conhecer como centro da história do povo que o reconhece e se abre em diálogo com Ele. Uma dessas confissões que marcaram a história de Israel, marca também a nossa história nos dias de hoje: "Meu pai era um arameu errante.: Ele desceu ao Egito e ali residiu com poucas pessoas; depois tornou-se uma grande nação. Os egípcios porém, nos maltrataram e humilharam, impondo-nos dura escravidão. Clamamos a Javé que ouviu nossa voz e nos fez sair do Egito com sinais e prodígios, e nos trouxe a este lugar, dando-nos esta terra, onde corre leite e mel. Por isso, trago os frutos da terra que tu me deste, Javé!" (Dt 26, 5-10).

Se pensarmos bem, todos os grandes paradigmas humanos e religiosos têm uma teologia da história. Os exemplos do Antigo Testamento, são interpretados como verdadeiros testemunhos desta afirmação. Os acontecimentos do Êxodo que levaram o povo de Israel a se conscientizar de que Javé tomava a iniciativa na vida do povo fazendo aliança com ele, cumprindo a promessa que se manifestava na posse da terra, na vinda do Messias Libertador anunciado pelos Profetas, enfim, os textos sobre a vida do Messias na pessoa de Jesus que anuncia a vinda do Reino em meio a seu povo, constituem o fundamento da teologia da história.

Nesse sentido, a história passa a ter um significado de mistério, o qual manifesta sempre a ação salvífica que, "a seu tempo Deus lhes dá o alimento" (S1 104,27). Esse tempo denota o tempo de Deus, na história, que dá 
motivo de esperança para a caminhada terrena. Em Jesus Cristo cumpriu-se o tempo de Deus e sua continuidade se dá no testemunho da Igreja que busca dar ao tempo histórico um significado teológico. Por isso, para o cristianismo, a história é uma categoria teológica fundamental, pois o cristianismo nasce de fatos históricos, tem sua origem na revelação de Deus, no cumprimento da Promessa, que realiza a esperança fazendo nova a história do Deus encarnado em meio ao seu povo.

\section{A esperança em Puebla}

A esperança em Puebla consistiu, em primeiro lugar, por ter sido um acontecimento que ratificou aquilo que Medellín disse com sua força profética. Ainda que se tenha feito acirradas críticas ao documento, ainda que se tenha feito corajosas análises de seu texto e levantado perspectivas nem sempre possíveis, este documento tem uma teologia da história que nos leva a sistematizá-la com interesse, porque é vivida num contexto de esperança. Esta esperança como teologia da história está dentro da caminhada de fé dos nossos povos, está na prática pastoral, está na sua teologia que a fundamenta e sobretudo, está no testemunho de fé comprometida com a construção do Reino, dos nossos mártires vivos e plenificados na vida em Cristo. Numa palavra, Puebla é um 'espírito', antes de ser um documento, e, nesta perspectiva, devem ser lidas e aplicadas as orientações da Conferência.

Se Medellín é o documento considerado fundador de uma abertura renovadora e inspiradora para a história dos povos que habitam e vivem sua fé neste Continente, o documento de Puebla é considerado a confirmação de tudo aquilo que foi 'batizado' em Medellín. Tanto os bispos, quanto os teólogos e cientistas sociais que assessoraram o acontecimento de Puebla, tiveram que dispensar atenção redobrada para que os bons ventos da renovação trazidos por Medellín, não fossem ofuscados. Ao falar deste acontecimento, deixaram transparecer a força da esperança que havia em todos, e de modo especial, nas orientações e decisões tomadas em conjunto ${ }^{26}$. Fora do Brasil, sobretudo na Igreja da Europa, Puebla foi interpretada como um marco de esperança histórica que jamais se apagaria em tempo algum: a Igreja da América Latina tomara consciência de que devia projetar-se para além de suas próprias fronteiras, devia projetar-se ad gentes. A dimensão e o destino universal da evangelização na América Latina podia, finalmente, oferecer algo

${ }^{26}$ Cf. LIBÂNIO, J. B., Conferências Gerais do Episcopado Latino-Americano do Rio de Janeiro a Aparecida, S. Paulo, Paulus, 2007, p. 27ss. 
de original e importante para todas as Igrejas do mundo. Podia oferecer sobretudo, sua esperança e a jovialidade de sua fé $^{27}$. Numa palavra, dar de sua riqueza com um povo empobrecido.

Foi necessário grande esforço para ler e interpretar de forma positiva as diferenciadas intervenções de grande parte de bispos que aí representavam seu povo através das Conferências de cada país. Os bispos fizeram seu trabalho dentro dos limites que sabemos. A aplicação das orientações e propostas concretas assumidas por eles em assembléia, tiveram êxito pela sua receptio viva das bases, e do povo em geral. Não separamos a teologia da história que a caracteriza e que dá um sentido de fé e de esperança aos fatos, aos acontecimentos e até mesmo aos eventos da vida política, social e religiosa dos nossos povos. Mas, nesse contexto, a atitude profética dos bispos em Puebla transmitem e comunicam esperança aos povos do Continente que vivem situações históricas necessitadas de transformação, buscam iluminar as difíceis situações vividas por seu povo. O foco de seu pronunciamento é a promessa feita por Cristo que transcende sempre as encarnações históricas ${ }^{28}$. A reflexão feita por muitos dos nossos teólogos, ensina que o aspecto teológico das conquistas humanas trazem em si mesmas as perspectivas que têm como objeto a "a plenitude dos tempos" $(\mathrm{Gl} 4,4)$.

Puebla insiste que a urgência desta transformação interpela a fé das pessoas para que vivam um cristianismo comprometido com os valores do Evangelho e os ensinamentos deixados por Jesus Cristo. Os bispos convocam todas as pessoas de boa vontade a uma conversão individual e social. Pedem aos cristãos que colaborem para a construção de uma história que transforme as pessoas e as estruturas sistêmicas e culturais dentro das quais vivem sua fé. Pedem ainda que comuniquem seus valores cristãos à cultura global em que estão inseridos, e, conscientes dos resultados já obtidos, tenham esperança de continuar trabalhando pelo seu aperfeiçoamento ${ }^{29}$.

No mesmo espírito de Medellín, que coloca a celebração da prática e da vida de fé na celebração litúrgica, Puebla afirma que o gesto litúrgico de louvor e comunhão com Deus, Comunidade de amor, faz com que a ação do Espírito Santo encarne o Evangelho na história e torne o trabalho humano, um sinal da revelação de Deus, na história. O ato litúrgico nos faz participar do mistério pascal de Cristo que, com sua solidariedade, nos torna capazes

\footnotetext{
${ }^{27}$ Cf. Documento de Puebla, n. 368. Ver também BOFF, L., "A Libertação em Puebla”, in AA.VV., Puebla: análise, perspectivas, interrogações, S. Paulo, Paulinas, 1979, p. 43

28 Documento de Puebla, 188. COMBLIN, J., "Evangelização na atualidade", in América Latina: 500 anos de evangelização, S. Paulo, Paulinas, 1990, p. 45 e 240.

${ }^{29}$ Cf. AA.VV. Vida, clamor e esperança. Reflexões para os 500 anos de evangelização a partir da América Latina, S. Paulo, Loyola, 1992, p. 233s.
} 
de transformar a nossa esperança em realidade que faz a nova história e nos torna protagonistas com Ele, na construção da convivência humana.

Ao examinarem a realidade desse ponto de vista, os bispos relacionam como sinais de esperança, na história, que apontam para a prática de Jesus Cristo que pregou o Reino, algumas qualidades humanas que faz do nosso povo ser um povo profundamente religioso e sensível aos valores humanos e solidários que marcam a cultura e a diversidade de sua fé. A fé se manifesta numa religiosidade, através da qual o povo se evangeliza a si mesmo. Sinais de esperança são, para o documento de Puebla, valores humanos vividos e testemunhados como expressões autênticas da fé cristã ${ }^{30}$.

Os bispos afirmam ainda que, nossos povos vivem uma tendência inata de partilhar o que têm com as pessoas mais pobres, tanto bens materiais casa, comida, roupa - como bens morais e espirituais - acolhimento, atenção, afeto. Valorizam os vínculos da amizade e prezam as relações que se estabelecem dentro e fora da família. Com abertura e ousadia, tomam consciência cada vez mais clara da própria dignidade, e cada vez mais luta pela participação nas organizações de todos os segmentos da sociedade, no interesse de manifestar os valores de sua originalidade como povo e nação. Cultivam um conhecimento prático de que todas as pessoas podem melhorar sua qualidade de vida. Assumem com ousadia como dever, o fato de conseguir resultados no campo da educação, da saúde, da comunicação em todos os sentidos e da própria representatividade ${ }^{31}$.

Concluem esta relação de valores reconhecendo que a vivência de tais valores, em todas estas instâncias sociais e humanas, faz do nosso povo um protagonista no modo de viver o cristianismo de um jeito novo e original, fazendo emergir de dentro desta prática, as sementes que aí já se encontram na cultura, sementes trazidas pela encarnação do Verbo, como ensina $a E$ vangelii Nuntiandi de Paulo VI ${ }^{32}$.

Enfim, a esperança que pervadiu o acontecimento de Puebla é vivida na reação das comunidades de fé, que por um lado respondem entusiasmadas às inovações pós-conciliares e por outro a reação de grupos e comunidades que se sentem inseguras diante das iniciativas já em ato no Continente ${ }^{33}$. Esta experiência continua levando a Igreja a avançar pelos lados sem perda

\footnotetext{
${ }^{30}$ Documento de Puebla, 188.

${ }^{31}$ Ibid., n. 17-21

${ }^{32}$ Cf. AA.VV., Vida, clamor e esperança. Reflexões para os 500 anos de evangelização a partir da América Latina, S. Paulo, Loyola, 1992, p. 108ss.

${ }^{33}$ Cf. Documento de Puebla, 435; BOFF, L., Puebla: interpretações, comentários, perspectivas, Petrópolis, Vozes, 1979, p. 199.
} 
de tempo, pois, ainda hoje, há grupos e igrejas inteiras que resistem às inovações trazidas pelo Vaticano II e os avanços que este tem realizado e continua realizando em nossa realidade continental. Não só, mas está levando a Igreja do Espírito Santo a abrir as comportas da sadia tradição do catolicismo da Reforma e da Restauração, realizadas em nosso processo evangelizador continental, com a finalidade de revestir, com a roupa nova do Vaticano II, valores religiosos e cristãos que guardam a essência da verdade de fé, nascida da experiência do povo simples e pobre.

\section{Ressonâncias teológicas vindas do contexto histórico}

No primeiro capítulo do documento que trata do conteúdo da evangelização, Cristo é apresentado como "força motora da nossa história". O Cristo vivo, presente e atuante na história humana, é apresentado como "o Senhor da História" 34 . A esperança como teologia da história, apresenta ainda, características que nascem das justas aspirações de nossos povos, que se expressam por sua irrenunciável dimensão religiosa, sua busca de Deus, do Reino que Jesus Cristo nos trouxe, para que possam se tornar sempre mais pessoas de esperança e sujeitos da nova história ${ }^{35}$. Os bispos reconhecem que há uma tomada de consciência por parte das pessoas de realizarem estas aspirações sem esgotamento das mesmas no quadro da existência temporal, esperança que, ainda de modo imperfeito e limitado, começa sua realização na construção de uma nova história ${ }^{36}$.

Os bispos em Puebla esclarecem o grande sentido do mistério da Encarnação como último fundamento da história humana, a qual abre a interpretação cristológica da vida histórica de Jesus que progride através do tempo e se plenifica no mistério pascal. Este mistério é o coração da esperança como teologia da história: "É dever nosso anunciar claramente, ... o mistério da Encarnação, tanto a divindade de Jesus Cristo, tal como a professa a fé da Igreja, quanto a realidade e a força de sua dimensão humana e histórica". Depreende-se desta orientação pastoral, fundada na fé professada pela Igreja de todos os tempos, de que Jesus, o Cristo da fé, é a norma universal de toda a história e o seu centro ${ }^{37}$. Contudo, não se deve deixar de "apresentar Jesus

\footnotetext{
${ }^{34}$ Documento de Puebla, nn. 174-175; $177 ; 178$.

${ }^{35}$ Cf. Ibid., 131-132; 135.

${ }^{36}$ Cf. Ibid., 274; MOLTMANN, J., La Chiesa nella forza dello Spirito, Brescia, Queriniana, 1976, p. 77s. DP, 141.

${ }^{37}$ Documento de Puebla, 173.176; Cf. IMPERATORI, M., H.U. Von Balthasar: una teologia drammatica della storia, Pubblicazioni del Pontifício Seminário Lombardo in Roma, 2001, p. 4-5. Ver também, ROXO, R. M., O Senhor e a História, Petrópolis, Vozes, 1969, p. 133s.
} 
de Nazaré compartilhando a vida, as esperanças e as angústias do seu povo e mostrar que Ele é o Cristo crido, proclamado e celebrado pela Igreja",38.

A esperança como teologia da história, é reconhecida também, quando o documento afirma que no centro da história humana foi implantado o Reino de Deus na face do Cristo ressuscitado, fazendo nova a antiga história, completando-a com o princípio da história nova ${ }^{39}$. A concepção teológica de história prossegue ainda, neste documento, ao afirmar que os cristãos fazem a diferença diante dos desafios de uma história entregue, inteiramente, à ação de Deus que intervém diretamente na história e diante de outros que, numa perspectiva de considerar Deus distante da história humana, assumem a responsabilidade de construírem, por conta própria, toda história da humanidade.

Responde o documento na palavra dos pastores: Não foi assim que Jesus Cristo agiu: Ele encontrou Deus Pai em meio a sua história, forjando, em aliança com seu povo, a história da salvação. Por sua atitude, Jesus é apresentado atuando na história pela "mão" de seu Pai, em co-responsabilidade e compromisso com a vontade do Pai. Ao mesmo tempo que o Pai cuida das aves do céu e dos lírios do campo (cf. Lc 12, 22-23), sabe também que o Pai atua através da ação do Filho. Não basta esperar a hora, é preciso construí-la, preveni-la e até mesmo antecipá-la, perscrutando os sinais da Providência, pois desse processo todo, depende a concretização antecipatória da nova história. Esta depende também das mediações sociais, embora limitadas, para que a esperança que alimentamos no fim bom da história, realize a Promessa que ocupa o centro de todos os sistemas históricos abertos ${ }^{40}$.

Para a comunhão se orienta toda a história da salvação ${ }^{41}$. Desta concepção nasce a urgência de a Igreja ser uma escola onde se eduquem mulheres e homens forjadores e capazes de fazer história, para levar, eficazmente, com Cristo, a história dos nossos povos à plenitude do Reino. Jesus foi um homem que se tornou o centro da história pela sua vida e pela sua prática. Nele culminou a sabedoria ensinada por Deus a Israel que o encontrou em meio a sua história e com Ele fez a nova história porque construída em aliança $^{42}$.

\footnotetext{
${ }^{38}$ Documento de Puebla, 176.

${ }^{39}$ Cf. Documento de Puebla, 197.

${ }^{40}$ Cf. Ibid., 274 a 277. Faça um cf. também com RATZINGER, J., San Bonaventura. La teologia della storia, Cittá del Vaticano, Assisi, Porziuncola, 2008, p. 27s.

${ }^{41}$ Cf. Documento de Puebla, n. 199; 213.214.

${ }^{42}$ Cf. Ibid., n. 275; 276.
} 


\section{A esperança em Santo Domingo}

Quanto à Conferência de Santo Domingo ${ }^{43}$, na leitura interpretativa e na visão de expressivo grupo de teólogos, não foi a confirmação de Medellín e Puebla, como gostaríamos que tivesse sido: foi uma terceira coisa, foi um "ajuste pastoral" no sentido de retomar a caminhada tradicional da Igreja latino-americana, partindo de um outro contexto, com outra sensibilidade e numa outra ótica ${ }^{44}$. Segundo as diferenciadas análises feitas, a tese do "ajuste pastoral" é evidente nos sinais inequívocos da alteração que os bispos fizeram na missão evangelizadora da Igreja - que não é o caso de falar destes sinais agora - mas apenas lembrar que foram claros na mudança da linguagem pastoral - não se podia falar em libertação - e na mudança de método aboliram o ver, o julgar e o agir. Poder-se-ia dizer: "Santo Domingo é música latino-americana tocada com guitarra romana" 45 .

Como assimilar as conclusões do documento de Santo Domingo na nossa caminhada? Em primeiro lugar, importa receber o documento no espírito e na dinâmica da tradição eclesial, como nos fala a Dei Verbum: "O que foi transmitido pelos Apóstolos compreende todas aquelas coisas que contribuem para, santamente, conduzir a vida e fazer crescer a fé do Povo de Deus, e assim a Igreja, em sua doutrina, vida e culto, perpetua e transmite a todas as gerações tudo o que ela é, tudo o que crê" (DV 8).

O Santo Domingo histórico é uma coisa; o Santo Domingo querigmático é outra. Os dois estão unidos, sendo que um supõe o outro" ${ }^{46}$. A aplicação de suas orientações nos movimentos eclesiais, nas CEBs, numa palavra, o sensus fidelium conferido pelo Espírito Santo a todo o Povo de Deus, permite uma percepção ativa da Palavra de fé, inclusive a do magistério. A marca histórica deste momento da igreja latino-americana e os sinais de esperança deixados por ele, continuam se encontrando na Encarnação da graça - Jesus Cristo e seu Mistério Pascal - que não se fecha nem mesmo aos nossos bispos,

A Conferência de Santo Domingo, mesmo em meio aos seus muitos condicionamentos, acabou nos deixando lições a fazer e caminhos a seguir, como povo de esperança e povo capaz de mudar sua história diante dos ques-

\footnotetext{
${ }^{43}$ Cf. AA.VV., Santo Domingo. Ensaios Teológico-Pastorais, Petrópolis, em co-edição SOTER, Vozes, Ameríndia, 1993.

${ }^{44}$ Cf. LIBÃNIO, J. B., Conferências Gerais do Episcopado Latino-Americano do Rio de Janeiro a Aparecida, S. Paulo, Paulus, p. 27-36; BOFF, Cl., O "evangelho" de Santo Domingo. Os dez temas-eixo do Documento da IV CELAM, Petrópolis, Vozes, 1994, p. 26.

${ }^{45} \mathrm{BOFF}, \mathrm{Cl}$., $O$ "evangelho de Santo Domingo...", o. c., p. 27.

${ }^{46}$ Cf. BOFF, Cl., o. c., p. 61. Cf. AA.VV., Santo Domingo. Ensaios Teológico-Pastorais, Petrópolis em co-edição: SOTER, Vozes, Ameríndia, 1992, p 46-48.
} 
tionamentos feitos, interna e externamente, à estrutura eclesiástica. Em primeiro lugar, o documento publicado não deixa de afirmar, claramente, sua continuidade com Medellín e Puebla ${ }^{47}$, alarga suas orientações pastorais na perspectiva de uma nova evangelização que não contradiz o Vaticano II, o qual, não só inspirou nossas Conferências de Medellín e Puebla, mas foram, sua aplicação na realidade latino-americana ${ }^{48}$.

Neste espírito, a concepção de que a esperança como teologia da história passa por mediações do momento conjuntural da caminhada de fé do povo, tomamos os pontos que nos pareceram significativos e têm a ver com a esperança como teologia da história, sobretudo no discurso de abertura da Conferência feito por João Paulo II.

Diante das críticas que foram feitas ao documento, deixá-lo de lado ou desconhecê-lo, seria demonstrar falta de inteligência histórica e esvaziar a esperança que nasce da fé que leva à construção da nova história. O discurso de abertura de João Paulo II, coloca, sob o signo da esperança, a nova era que está começando com a aproximação do terceiro milênio e a celebração dos quinhentos anos de evangelização do nosso continente ${ }^{49}$. Narrar e celebrar os feitos do Senhor na história, é uma atitude profundamente, bíblica que dá esperança e alimenta a dinâmica da fé.

A esperança marca a árdua tarefa reservada aos bispos como pastores; esta tarefa, porém, está ancorada no Cristo Ressuscitado e é raiz de todo o processo de evangelização nos seus distintos aspectos ${ }^{50}$. Prosseguindo em seu discurso, João Paulo II exorta os bispos a estarem sempre prontos "a dar razão da própria esperança" $(1 \mathrm{Pd} 3,5)$, a cada pessoa encontrada no caminho da sofrida realidade continental ${ }^{51}$, pois esta se apóia nas promessas de Deus, na fidelidade à sua palavra e na vitória definitiva sobre o pecado e a morte.

O que impressiona, neste documento, é que Santo Domingo deixou de recuperar, através do magistério papal, aquelas intuições pastorais da Igreja continental que o próprio João Paulo II, em seu discurso, tinha incorporado, ao se referir aos avanços da caminhada de fé dos nossos povos. É o caso, por exemplo, das indicações feitas a Montesinos, Las Casas, Córdoba, Frei Juan

\footnotetext{
${ }^{47}$ Por dezena de vezes foi feita esta constatação.

48 Documento de Santo Domingo. IV Conferência Geral do CELAM: Nova Evangelização Promoção Humana Cultura Cristã, Petrópolis, Vozes, 1992, 287

${ }^{49}$ Ibid., discurso de abertura de João Paulo II, 25

${ }^{50}$ Documento de Santo Domingo, texto oficial da CNBB, Petrópolis, Vozes, 1992, 25. Cf. AA.VV., Santo Domingo. Ensaios Teológico-Pastorais, Petrópolis, SOTER/Vozes/Ameríndia, 1993, p.82-83.

${ }^{51}$ Cf. Documento de Santo Domingo, 107 ss e 244ss. Cf. Santo Domingo. Ensaios TeológicoPastorais, o. c. p. 90s.
} 
del Valle e tantos outros, que clamaram a favor dos povos oprimidos de seu tempo, marcando a história com sua consciência profética na cátedra da dignidade e da liberdade da pessoa humana. Esta "parresía" foi apresentada, pelo papa, como o selo da ação pastoral dos bispos, que "nada vos pode fazer calar" ${ }^{52}$. Acrescentou ainda o pontífice, esta é a linguagem trazida por Jesus Cristo, porque se encontra no Novo Testamento. Afirmou também que o Concílio Vaticano II deve ser o ponto de referência obrigatório na vida e na missão de todo o pastor, citando a Gaudium et spes, 2.

Ao longo de seu discurso, citou, generosamente, quase todas as encíclicas e exortações pastorais e sociais do magistério papal recente, tais como a Evangelii Nuntiandi, Centesimus annus, Redemptoris mission, Libertatis nuntius, Libertatis conscientia, Populorum progressio, Laborem exercens, Sollicitudo rei socialis, que descortinam um amplo horizonte de visão pastoral e de espiritualidade em seu significado mais profundo e abrangente de fé compromissada e não justaposta ao religioso. Poderia-se deduzir que, enquanto João Paulo II procurou ser latino-americano, o documento de Santo Domingo se esforçou por se fazer, culturalmente, menos universalista, como Igreja.

No entanto, em seu discurso de abertura, o papa dá o fundamento da esperança com estas palavras, ao dirigir-se aos bispos: "A tarefa que vos espera nos próximos dias é árdua, mas está marcada pelo signo da esperança que vem de Cristo Ressuscitado. Vossa missão é a de serdes arautos da esperança de que nos fala o apóstolo Pedro (cf. 1Pd 3,15): esperança que se apóia nas promessas de Deus, na fidelidade à sua palavra e que tem como certeza inquebrantável, a ressurreição de Cristo....53.

A esperança como teologia da história, relendo as Conferências realizadas em nosso continente, vamos encontrá-la explicitada também, no documento de Aparecida que será apresentado num segundo artigo desta Revista.

\section{Ressonâncias teológicas vindas do contexto histórico}

Todo o documento mantém viva a memória histórica da evangelização do continente e a história é apresentada como "mestra de vida", na medida em que pode inspirar, pastores e povo de Deus, as coisas boas que realizamos e advertir os nossos desacertos e erros ${ }^{54}$.

\footnotetext{
${ }^{52}$ Documento de Santo Domingo: discurso de abertura, 4. 10. 25.

${ }^{53}$ Ibid., 25.

${ }^{54}$ Documento de Santo Domingo, 248
} 
$\mathrm{O}$ pronunciamento de abertura do papa atribui um valor teológico à história da evangelização quando afirma - como em Puebla - que Jesus Cristo é "o Senhor da história". Ao apresentar a ação concreta da evangelização, o pontífice afirma, que os pastores não lidam com pessoas abstratas, mas com gente que não conseguiu mudar sua história para viver com dignidade sua vocação de filhos e filhas de Deus. Prossegue, incluindo os povos do extenso continente na urgente solidariedade internacional,como exigência de aumentar os meios de distribuir os bens da criação com justiça, instaurando uma verdadeira economia de comunhão e participação ${ }^{55}$.

Esta expressão parece ter tido um significado fraco diante do "rosto de igreja" apresentado de forma ambivalente em tantos parágrafos do documento. Este deixou ver bastante claro o debate teológico interno da igreja, que busca solucionar a questão das duas eclesiologias da Lumen gentium: a do capítulo II, "Povo de Deus" e a do capítulo II, "Constituição hierárquica da Igreja" . Neste quadro, o sentido que o documento dá à "comunhão participação", precisa ser retomado para maior aprofundamento e abrangência da eclesiologia pós-conciliar.

A proclamação de que Jesus Cristo é a nossa esperança e é o centro da nossa história, expressa bem o momento que a nossa Igreja Continental estava vivendo: uma encruzilhada histórica que leva o povo das bases a projetar, sobre Santo Domingo, a luz do Vaticano II, de Medellín e de Puebla, dado que sabemos, por experiência, quem acompanha estas conferências que se dão para além das nossas Igrejas locais: são pessoas, grupos eclesiais e organizações comprometidas com o bem, que se interessam por uma Igreja dialogante e aberta às questões que dizem respeito a todos e a todas.

Pode-se afirmar, que Santo Domingo teve a grandeza de realizar esta Conferência que não ficará na história apenas pelo documento que produziu, mas pelo movimento que desencadeou, no sentido de que, diante do impasse histórico, o protagonismo é dado ao Espírito Santo, como sopro mais profundo da ação do povo que vive sua fé, ainda que "iletrado". As lições dadas por Santo Domingo e os ganhos, em potência, que ele nos traz, podem ser assim elencados: a nova evangelização nos leva a fazer um pedido de perdão dos nossos erros históricos para uma retomada da tarefa missionária; a promoção humana nos mostra o fenômeno da exclusão social e a urgência de criar uma cultura de vida para um nova ordem social, sintetizada na econo-

\footnotetext{
${ }^{55}$ P 15-17. Cf. SAYER, J., "O discurso programático de João Paulo II e sua importância para Santo Domingo", in AA.VV., Santo Domingo. Ensaios Teológico-Pastorais, o. c., p. 84-85.

${ }^{56}$ Cf. BOFF, Cl., "Análise global do Documento da IV CELAM", in AA.VV., Santo Domingo. Ensaios Teológico-Pastorais, Petrópolis, SOTER/Vozes/Ameríndia, 1993, p. 40-44.
} 
mia solidária, na política ética e na cultura pluralista. Esta última foi a "marca registrada" de Santo Domingo, incluindo a integração continental. Se realizarmos estas lições em nossa vida de fé, de ensinamento e de prática pastoral, Santo Domingo é a revelação da graça encarnada.

\section{A modo de conclusão}

Os nossos bispos que participaram das muitas sessões do Vaticano II realizado em Roma, sentiram forte a urgência de abrir e adequar a Igreja missionária do continente, às orientações pastorais assumidas por todos os bispos das Igrejas Cristãs, neste Concílio Ecumênico. Tentou-se delinear alguns aspectos desta situação eclesial, fazendo uma releitura das nossas Conferências Episcopais à luz da esperança, não como virtude teologal, mas como teologia da história, isto é, como experiência de fé feita num contexto histórico concreto.

Medellín foi o documento apresentado como grito de partida e batismo de iniciação para a criação de um novo jeito de viver a Igreja fundada por Jesus Cristo com seu Mistério Pascal, de vida, pregação, paixão, morte e ressurreição para a Nova Criação.

Puebla teve o privilégio de confirmar os pontos essenciais assumidos por Medellín. Os bispos e os cardeais que estiveram presentes neste evento, assim como os teólogos e cientistas sociais, haviam passado pela experiência e pelas discussões de esclarecimento do Concílio Ecumênico. Se Puebla teve suas dificuldades para a aprovação de seu documento, teve também seus merecidos méritos.

E Santo Domingo, dando continuidade a Medellín e Puebla, apresentou um documento preocupado com a cultura e a inculturação do anúncio do Cristo Ressuscitado em todo o Continente.

Toda esta caminhada foi feita à luz da esperança que caracteriza os nossos povos como o Continente da Esperança, na fé em Jesus Cristo, que se dá como experiência inculturada e encarnada no contexto da nossa história, de acertos e de pedidos de perdão.

A esperança pervade a nossa experiência de fé na construção de uma história nova e aberta à ação de Deus que se revela em cada acontecimento. Importa o avanço dos nossos povos na caminhada de fé para a Terra Prometida que vislumbramos e entrevemos já no presente da nossa história. 


\title{
Resumo
}

O presente artigo se propôs refletir a esperança como teologia da história partindo da experiência latino-americana e caribenha vivida nas três primeiras Conferências Episcopais realizadas em nosso continente. A intuição do Vaticano II, que dá um sentido cristão à esperança e às angústias de todos os povos que buscam a construção de sua própria história, é aplicada, em nosso continente, através das conclusões de Medellín e confirmadas em Puebla. A esperança vivida num contexto histórico de fé cristã é concebida como teologia da história, pois tem a missão de assumir os fatos e os acontecimentos que transcendem a história humana para fazer desta a história da salvação.

\section{Résumé}

L'article propose une réflexion sur l'espérance comme théologie de l'histoire à partir de l'expérience latino-américain et des Caraỉbes présentées dans les trois premières Conférences Episcopales réalisée dans notre continent. L'intuition du Concile Vatican II qui donne un sens chrétien à l'espérance et aux angoisses de tous les peuples qui cherchent la construction de leur propre histoire est appliquée dans notre continent par le document conclusif de Medellin et a été confirmée à Puebla. L'espoir vécu dans un contexte historique de la foi chrétienne est conçu comme théologie de l'histoire, pour avoir la mission de prendre en charge les faits et les événements qui transcendent l'histoire humaine pour en faire l'histoire du salut.

\author{
Lina Boff \\ Professora do Departamento de Teologia da PUC-Rio \\ Professora convidada pelo Antonianum de Roma \\ Professora de Mariologia na Faculdade Teológica dos Franciscanos de \\ Petrópolis
}

